\title{
Physical Behaviour of Foamed Concrete under Uni-Axial Compressive Load: Confined Compressive Test
}

\author{
Mohd Zairul Affindy Abdul Rahman \\ Faculty of Civil and Environmental Engineering \\ Faculty of Mechanical and Manufacturing Engineering, Universiti Tun Hussein Onn Malaysia \\ 86400 Parit Raja, Johore, Malaysia \\ E-mail: zairulaffindy@yahoo.co.uk \\ Ahmad Mujahid Ahmad Zaidi (Corresponding author) \\ Faculty of Mechanical and Manufacturing Engineering, Universiti Tun Hussein Onn Malaysia \\ 86400 Parit Raja, Johore, Malaysia \\ E-mail: mujahid@uthm.edu.my \\ Ismail Abdul Rahman \\ Faculty of Civil and Environmental Engineering \\ Faculty of Mechanical and Manufacturing Engineering, Universiti Tun Hussein Onn Malaysia \\ 86400 Parit Raja, Johore, Malaysia \\ E-mail: ismailar@uthm.edu.my
}

\begin{abstract}
Foamed concrete now is a common material used in civil engineering work. There are increasing amount in research where foamed concrete are used primarily to resist compression force. In this research, physical behaviour of foamed concrete was investigated. Based on the past research, the compressive strength of foamed concrete typically proportioned to achieve only low compressive strength in unconfined condition. Standard compressive test were performed to obtain the compressive strength of foamed concrete. In this research, the confined condition is produced. Unconfined condition also was done, but here just focused on confined condition. The confined compressive test method consist of applying a compressive axial load to moulded cylinders at a rate which is within a prescribe range until failure occurs. The physical behaviour of foamed concrete under confined condition is the continuity of unconfined condition and will be the guidance to conduct the further research
\end{abstract}

Keywords: Foamed concrete, Confined compressive test, Mode of failure

\section{Introduction}

Foamed Concrete is widely used in construction industries. In many engineering application foamed concrete are frequently exposed to variety loading and a complex loading situation. There are increasing amount in research and application where foamed concrete are used primarily to resist compression force. Hence, to better understanding the foamed concrete behavior under compression loading and accompanied failure process is become importance. Foamed concrete is one of the lightweight concrete and it's referred to cellular material which is consisting of Portland cement, fine sand, water, foaming agent and compressed air(B.Dolton and C.Hannah, 2006). The different between foamed concrete and normal concrete is the use of aggregates in the foamed concrete was eliminated and been replaced by the homogenous cells created by air in the form of small bubble which utilize a stable air cell structure rather than traditional aggregate(Ahmad Zaidi,A.M.,A.Rahman,I. and Ahmad Zaidi N.H. 2008). Based on the past research, it has proved that foamed concrete has experience the similarity to cellular material behavior and it should capture the stress-strain cellular material curve. It is concluding that foamed concrete under unconfined compressive test not 
experienced three phase regime i.e.: elastic regime, plateau regime and densification regime and also does not captured the real behavior of foamed concrete. The morphology analysis shows that the foamed concrete behavior has the similarity to cellular material. Based on the mode of failure, it seems that foamed concrete under unconfined compressive test just not shows the behavior of cellular materials failure(Abdul Rahman, I, Abdul Rahman, M.Z.A and Ahmad Zaidi, A.M. 2008). The finding from the research might lead us to one conclusion which is the standard unconfined compressive test for normal concrete is probably not suitable to implement to foamed concrete to determine the compressive strength(Abdul Rahman, I, Abdul Rahman, M.Z.A and Ahmad Zaidi, A.M., 2008). In this paper, foamed concrete under uniaxial compressive test under confined condition are study. The aim is to look the morphology and behavior of foamed concrete under uniaxial compressive load (confined compressive test). It is important to look on the properties of foamed concrete under variety situation and factor and its can lead the researcher to contribute in improving the understanding and application in foamed concrete.

Foamed Concrete contains a large amount of voids where material that contains large amount of voids that can be divided into two groups based on their proportion of solid phase. The porous material can be measured by a dense matrix containing a fair amount of pores but remain less than around 30-40\% which is conventional approximate limit separating porous from cellular materials. The cellular material can be measured by material that contain a higher amount of pores and can no longer be described as matrices including voids(Eric Maire, Arnauld Fazekas, Luc Salvo, Remy Dendievel, Souhail Youssef, Peter Cloetens and Michel Letang. 2003). It is clear that foamed concrete is one of cellular material and is made up of an interconnected network of solids structures which forms the edges and faces of cells. Using the technique by introducing bubbles into the slurry (mix of cement and water), the bubbles are allowed growing and stabilizing and then solidifying the whole structure by cross-linking. The assembly of the cell with solid edges or faces, packed together so that they filled the space. The most important feature of a cellular solids is its relative density $\rho^{*} / \rho s$; that is, the density of the cellular material, $\rho^{*}$, divided by that of the solid from which the cell are made, ps(Lorna J.Gibson and Michael F. Ashby. 1997). The compressive stress-strain behavior can be divided into three regimes, elastic regime, plateau regime and densification regime(Ahmad Zaidi,A.M.,A.Rahman,I. and Ahmad Zaidi N.H. 2008).

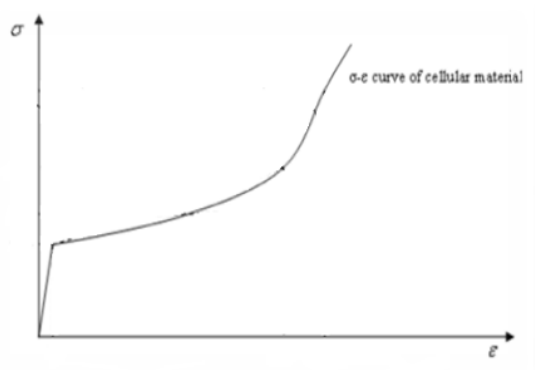

Figure 1. Stress-strain curve of cellular material

The result of foamed concrete under unconfined compressive test shows that the compressive strength typically proportioned to achieve only low compressive strength. Based on the schematic of stress-strain of cellular material, the graph produced by this unconfined condition was only going to an elastic regime which is the initial stage. Fig.1. shows the stress-strain curve. To complete the diagram, the curve supposed continue to next stage, plateau regime up to the densification strain and the densification regime, whereby the stress increases rapidly with the strain to complete the. All this happened due to the cracks which is propagated while the cylinder under compression(Abdul Rahman, I, Abdul Rahman, M.Z.A and Ahmad Zaidi, A.M. 2008). When crack just appears on the above part of the cylinder, the sample then going too failed. The universal testing machine automatically stopped the test and it's considered as failed(Abdul Rahman, M.Z.A, Ahmad Zaidi, A.M. and Abdul Rahman,I. 2008). Concrete is a combination of crushed, sand and a cement paste that binds the other component into solids. So concrete is brittle and have poor strength in strength but high in compression(Norman E. Dowling, 1993). Foamed concrete also is one of the brittle materials, but it has the combination of soft and brittle material so it can contain many micro cracks. When loaded in compression these micro cracks will propagated, which will cause the brittle material sample to fail(Zheming Zhu. 1999). Based on the observation under unconfined compressive test condition, as the load reached to $90 \%$ of the ultimate value, one may hear slight crack on the top part of the sample and its very clearly seen that most of the cracks were emcompass on the top part of cylinderical sample. Finally the cylinder collapsed with all the cracks occur in the top part of the cylinder and the compressive test does not make the collapse extended through the whole length of the cylinder(Abdul Rahman, I, Abdul Rahman, M.Z.A and Ahmad Zaidi, A.M. 2008). Fig.2. illustrates the failure modes of the unconfined compressive test as a top part failure due to early cracks initation(Abdul Rahman, M.Z.A, Ahmad Zaidi, A.M. and 
Abdul Rahman,I. 2008). According to foamed concrete condition under unconfined compressive test, it shows that under this condition, the sample failed due to early crack failure and also does not captured the real behavior of foamed concrete. The morphology analysis shows that the foamed concrete behavior has the similarity to cellular material (Abdul Rahman, I, Abdul Rahman, M.Z.A and Ahmad Zaidi, A.M. 2008).
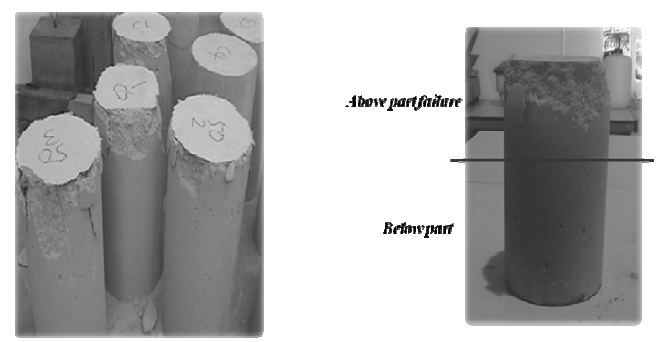

Figure 2. Part of failure of foamed concrete under unconfined condition

As the problem occur under unconfined condition is related to cracks, confined condition is produced to minimize the cracks and prevent sample during the compressive load test. The confinement will give the material supporting to prevent brittle collapse and it is well establish that external confinement of concrete cylinder enhances its strength and ductility.

\section{Sample Preparations}

In this study, plain foamed concrete is made of a combination of fine sand, cement, water and foam. The target density for this plain foamed concrete is within the range of $800 \mathrm{~kg} / \mathrm{m} 3-1000 \mathrm{~kg} / \mathrm{m} 3$. Below is the proposed design mix based on example of $1 \mathrm{~m}^{3}$ design mix of foamed concrete. In this research, confined condition is where the sample was confined with plastic wrappers. 6 samples were produced then were test using standard compressive load. The unconfined samples also were produced with the same batch and also undergo the standard compressive load.

Table 1. Mix design for foamed concrete

\begin{tabular}{|c|c|c|}
\hline No & Subject & Quantity \\
\hline 1 & Dry density $\left(\mathrm{Kg} / \mathrm{m}^{3}\right)$ & 799 \\
\hline 2 & Wet density $\left(\mathrm{Kg} / \mathrm{m}^{3}\right)$ & 940 \\
\hline 3 & Sand : cement $:$ water & $1: 1: 0.6$ \\
\hline 4 & Cement $(\mathrm{Kg})$ & 18.66 \\
\hline 5 & Dry sand $(\mathrm{Kg})$ & 18.66 \\
\hline 6 & Water $(\mathrm{Kg})$ & 11.18 \\
\hline 7 & Slurry density $\left(\mathrm{Kg} / \mathrm{m}^{3}\right)$ & 2005 \\
\hline 8 & Foaming Agent $(\mathrm{Liter})$ & 0.039 \\
\hline 9 & Water $(\mathrm{Liter})$ & 1.33 \\
\hline 10 & Foam $(\mathrm{Liter})$ & 28.78 \\
\hline
\end{tabular}

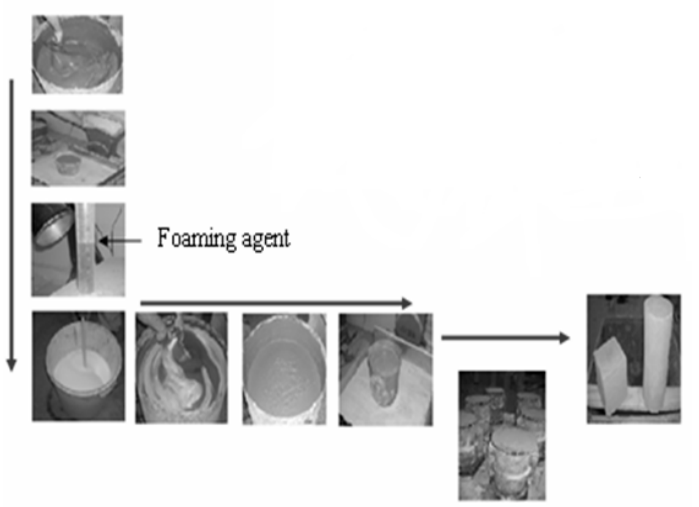

Figure 3. Manufacturing of foamed concrete 


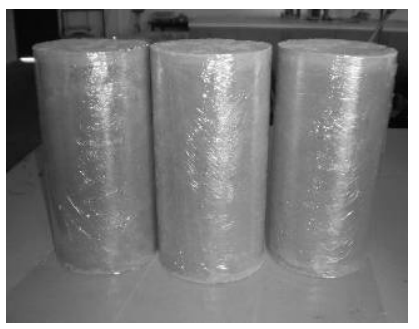

Figure 4. Foamed concrete sample under confined condition

\section{Experimental}

\subsection{Uni axial Compressive Load Test}

Compression test is performed to determine the behavior of materials under crushing loads. The samples compressed and deformation at various loads is recorded. The compressive strength test was performed based on compressive strength of cylinder concrete specimens - ASTM C39 standard. The purpose is to determine the compressive strength of cylinder foamed concrete (confined). The method is limited to concrete having a density of at least $800 \mathrm{~kg} / \mathrm{m} 3$ and 28 days compressive strength of molded cylinder is normally used in design. The specimen's size is 150 in diameter and $300 \mathrm{~mm}$ in height(Abdul Rahman, I, Abdul Rahman, M.Z.A and Ahmad Zaidi, A.M. 2008). Sample were wrapped using plastic wrapper to exist the confined condition to the sample. Foamed concrete sample will be tested under compressive load (confined) to determine the behavior of foamed concrete. All specimens were loaded uni-axially in compression until failure using a hydraulic testing machine (universal testing machine-UTM). From the result, we can get the maximum stress and also the displacement of the samples(Abdul Rahman, I, Abdul Rahman, M.Z.A and Ahmad Zaidi, A.M. 2008). Compressive stress and strain are calculated by dividing the maximum load attained during the test by the cross sectional area of specimens and a stress-strain diagram are plotted. The standard method for this test is according to standard test method for compressive strength of cylinder concrete specimens (ASTM: C39/C39M-01)( British standard. 2002). This test has the same procedure with the unconfined condition.

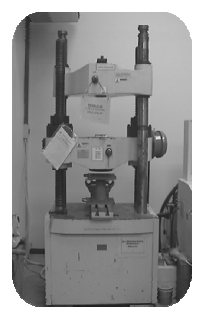

Figure 5. Picture of Universal Testing Machine

\section{Result and Discussion}

\subsection{Compressive Behavior}

Table2. below shows results of foamed concrete under confined compressive test. It shows that the compressive strength typically proportioned to achieve only low compressive strength. Based on the observation during the test, the confinement condition has reduced and slows down the crack propagation. The crack produced in big piece and automatically the micro cracks were reducing. It also increases the maximum load and prevents the material from brittle collapse for temporary period. But the confinement itself also has influence the result of maximum compressive strength. Generally the range of compressive strength is from 1 to $15 \mathrm{~N} / \mathrm{mm} 2$ (Ahmad Zaidi,A.M.,A.Rahman,I. and Ahmad Zaidi N.H. 2008). The result are achieved the maximum load at average of $17.03 \mathrm{kN}$ and average maximum compressive strength of $0.96 \mathrm{Mpa}$. This result is just only referring to an elastic regime which is initial stages. It has the same pattern compared to the unconfined condition. While the cylinders were under compressive test, it seems that, crack occurs and just appears on the above part of the cylinder then its going too failed. The cylindrical sample not failed extended through the whole length. The universal testing machine automatically stopped the test and it's considered as failed(Abdul Rahman, M.Z.A, Ahmad Zaidi, A.M. and Abdul Rahman,I. 2008). The test is failed due to early crack initiation. According to cellular material behavior, the compressive stress-strain behavior can be simplified into three regimes as shown in Figure1. Due to the cellular behaviors, the tests were only going to an elastic regime which is the initial stage. Fig.7. shows the stress-strain curve. The curve supposed continue to next stage, plateau regime up to the densification strain and the densification regime, whereby the stress increases rapidly with the strain(Ahmad 
Zaidi,A.M.,A.Rahman,I. and Ahmad Zaidi N.H. 2008). Fig.6 show the load-displacement curve where along the compression process, the displacement at every force which taken by the sample while the pressure are maintain until it reached the maximum load. The displacement is related to the dense of air voids and also in line with the rupture of the cell(Abdul Rahman, M.Z.A, Ahmad Zaidi, A.M. and Abdul Rahman,I. 2008).

\begin{tabular}{|c|c|c|c|c|c|}
\hline & & MAX & MAX & COMPRESSIVE & MAX \\
\hline \multirow[t]{2}{*}{ TYPE } & SAMPLE & FORCE & DISPLACEMENT & STRENGTH & STRAIN \\
\hline & & $\mathrm{kN}$ & $\mathrm{mm}$ & N/mm2/Mpa & $\%$ \\
\hline \multirow[t]{6}{*}{ CONFINED } & CF-1 & 17.78 & 5.47 & 1.01 & 1.82 \\
\hline & CF-2 & 14.5 & 2.91 & 0.82 & 0.97 \\
\hline & CF-3 & 16.5 & 6.14 & 0.93 & 2.05 \\
\hline & $\mathrm{CF}-4$ & 18.06 & 5.51 & 1.02 & 1.84 \\
\hline & CF-5 & 18.47 & 5.86 & 1.04 & 1.95 \\
\hline & CF-6 & 16.88 & 3.10 & 0.95 & 1.03 \\
\hline AVERAGE & & 17.03 & 4.83 & 0.96 & 1.61 \\
\hline
\end{tabular}

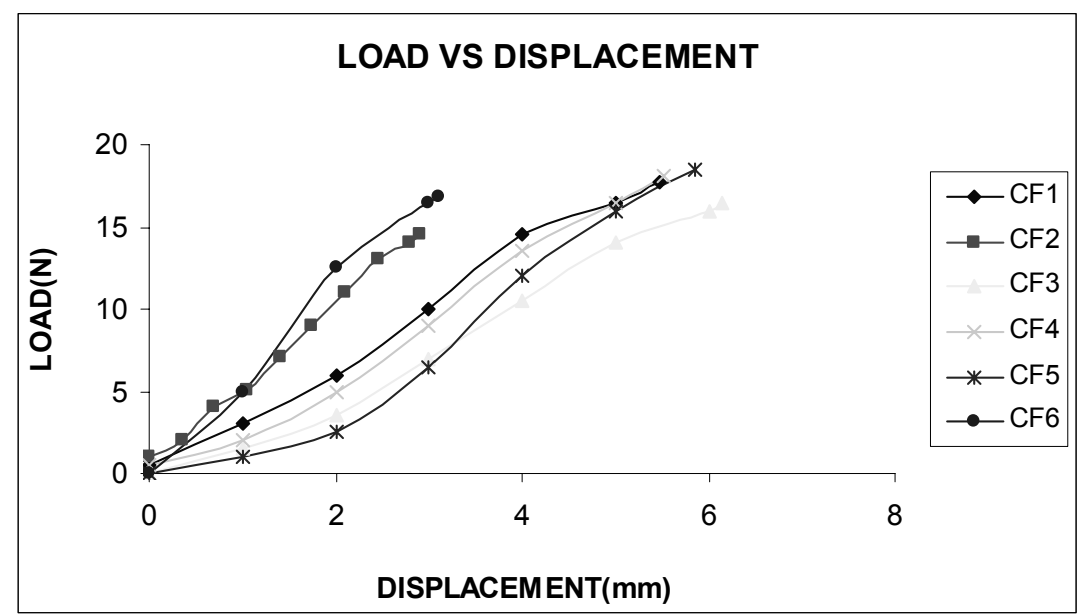

Figure 6. Compressive behavior of cylinder foamed concrete under Load-displacement Curve

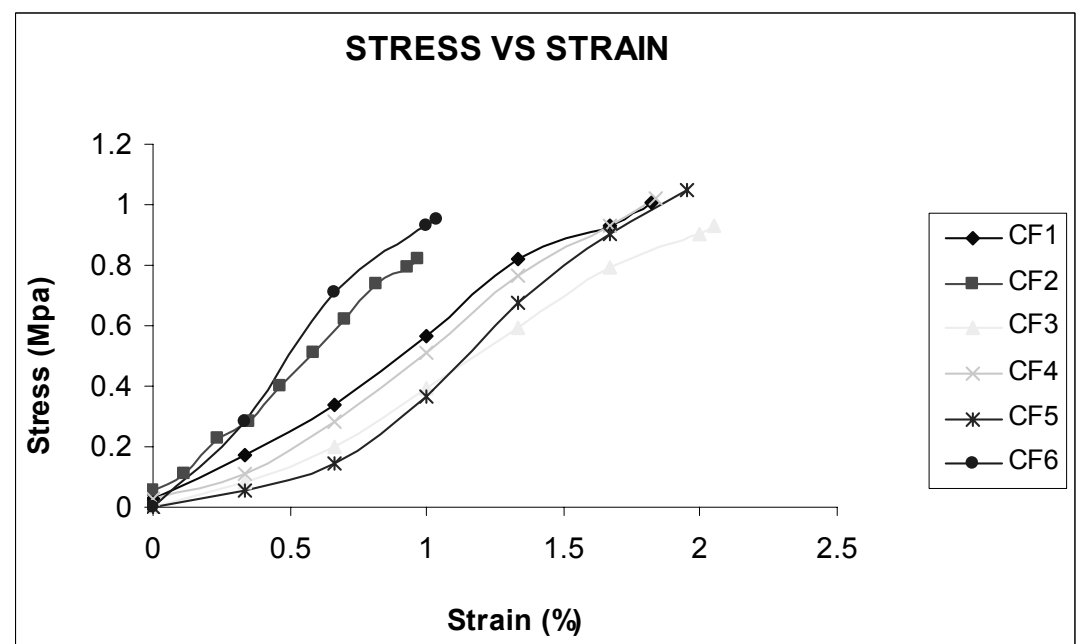

Figure 7. Compressive behavior of cylinder foamed concrete under Stress-Strain Curve 


\subsection{Mode of Failure}

Fig. 8 and fig.9. shows the failure modes of the plain foamed concrete after the compression test (confined). During the test, the crack occur at the top part of the sample. This time the crack is slow but it produces in big piece of crack. All the piece is just on the top part of the sample. Based on the confined condition, it really prevent the sample from brittle collapse. But it just for temporary basis as the load continued to be added, the cylinder suddenly collapsed with all the cracks occur in the top part of the cylinder. The confined compression test also does not make the collapse extended through the whole length of the cylinder. Fig.10. illustrates the failure modes of the unconfined compressive test as a top part failure due to early cracks initation(Abdul Rahman, M.Z.A, Ahmad Zaidi, A.M. and Abdul Rahman,I. 2008). This suggested that minor or crackles had generated from the beginning of the load is started to compress. Further increase the load, the cylinder was getting shorter and shorter and accompanied by the cracks failure. This factor is inline of the foamed concrete which has a combination of soft and brittle elements(Abdul Rahman, I, Abdul Rahman, M.Z.A and Ahmad Zaidi, A.M. 2008).

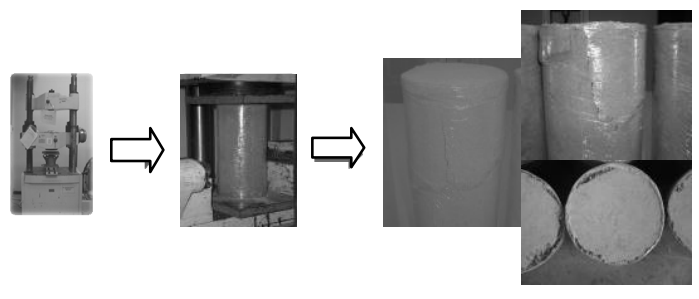

Figure 8. Failure modes of confined foamed concrete
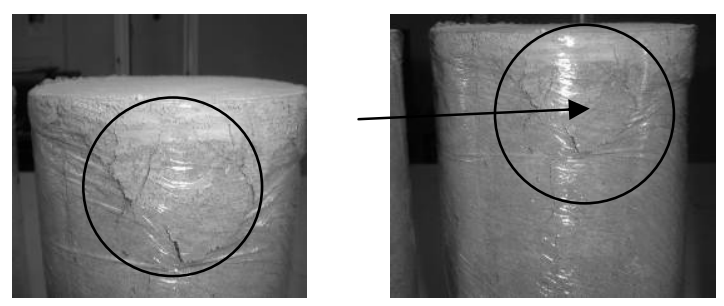

Figure 9. Part of failure of foamed concrete just upper part

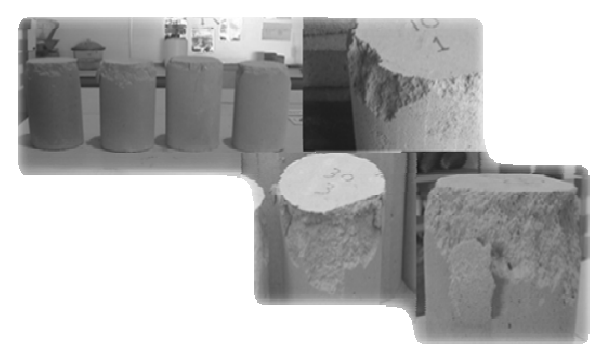

Figure 10. Mode of failure of foamed concrete under unconfined condition is similar like confined condition

(Abdul Rahman, I, Abdul Rahman, M.Z.A and Ahmad Zaidi, A.M. 2008)

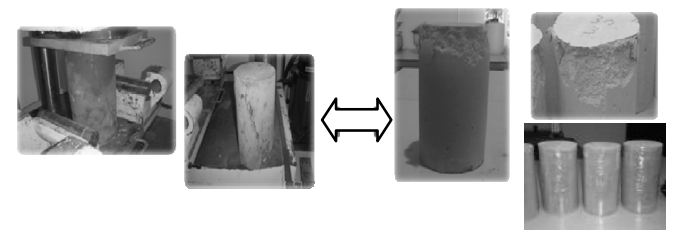

Figure 11. Comparison failure modes compared to natural concrete

(Abdul Rahman, I, Abdul Rahman, M.Z.A and Ahmad Zaidi, A.M. 2008) ${ }^{\mathrm{T}}$ 
Fig.11 shows the different between mode of failure of normal concrete and foamed concrete. According to BS EN 12390-3:2002, Testing hardened concrete, the mode of failure of foamed concrete does not have any similarity to normal concrete satisfactory failures(British standard. 2002). The confined condition failure has the same pattern failure with unconfined condition. It is shows that foamed concrete behavior does not same with normal concrete.

\section{Conclusion}

Foamed concrete behavior cannot be captured using the standard compressive test. Based on observation of unconfined condition and confined condition, it shows that foamed concrete under compressive test just give low compressive strength due to early crack failure. Confined condition is use to prevent the brittle collapse can reduce and slow down the crack from occur. Automatically confined condition has influence the compressive strength of foamed concrete itself. Confinement condition gives the sample more support and it was increase the compression strength compared to unconfined condition. The compression strength now influences by the plastic wrapper itself and this cannot capture the real strength of foamed concrete itself. Based on the result, foamed concrete under confinement condition give more strength result compared to unconfined condition and confinement condition also slow down the crack propagation which can make the sample failed due to early crack initiation. There is not much different result between confinement and unconfined condition to foamed concrete. The modes of failure of foamed concrete under confined and unconfined condition do not have similarity to normal concrete. This is because of it related to the dense of the cell of air voids that build the structure and the rupture of the cells. Overall, the compressive test of foamed concrete under unconfined condition and confined condition doesn't capture the real behavior of foamed concrete. Based on morphology analysis, it is proven that foamed concrete structure related to cellular material and it should capture the stress-strain cellular material curve. It is concluding that foamed concrete under unconfined compressive test not experienced three phase regime i.e.: elastic regime, plateau regime and densification regime. Standard compressive test for normal concrete is not suitable to implement to foamed concrete to determine the compressive strength. Suggestion that the foamed concrete compression test should use the method that can prevent crack from propagated and can be extending to the whole length of the sample while under compression condition. Then the three phase regime can be extract out using the test. Next study should be taken to investigate and look out for the suitable test for foamed concrete.

\section{References}

Abdul Rahman, I, Abdul Rahman, M.Z.A and Ahmad Zaidi, A.M. (2008). Morphology and physical behavior of foamed concrete under uniaxial compressive load: standard unconfined compressive test, UTHM Research Technical Report, pg 1-10.

Abdul Rahman, M.Z.A, Ahmad Zaidi, A.M. and Abdul Rahman,I. (2008). Investigation of physical behavior of foamed concrete under unconfined compressive test, $3^{\text {rd }}$ international conference on post graduate education : Multidisciplinary education, Pulau Pinang, Malaysia.

Ahmad Zaidi,A.M.,A.Rahman,I. and Ahmad Zaidi N.H. (2008). Behavior of fiber reinforced foamed concrete: Indentation test analysis, Proceeding of the seminar on geotechnical engineering UTHM, Johore, Malaysia, pg.92-101.

B.Dolton and C.Hannah. (2006). Cellular concrete : Engineering and technological advancement for construction in cold climates, The 2006 annual general conference of the Canadian society for civil engineering, Calgary Alberta, Canada, GC-125-1 - GC-125-11.

British standard. (2002). BS EN 12390-3:2002, Testing hardened concrete - part 3: compressive strength of test specimens, Pg.5-8.

Eric Maire, Arnauld Fazekas, Luc Salvo, Remy Dendievel, Souhail Youssef, Peter Cloetens and Michel Letang. (2003). X-ray tomography applied to the characterization of cellular materials. Related finite element modeling problems, Composite science and technology 63, pg. 2431-2443.

Lorna J.Gibson and Michael F. Ashby. (1997). Cellular solids: structure and properties-second edition, Cambridge University Press, pg.2-7.

Norman E. Dowling. (1993). mechanical behavior of materials, Prentice Hall, Englewood Cliffs, New Jersey, pg 81-82.

Zheming Zhu. (1999). New biaxial failure criterion for brittle material in compression, Journal of engineering mechanics, pg. 1251-1258. 